\title{
Inner Ear Lipoma
}

National Cancer Institute

\section{Source}

National Cancer Institute. Inner Ear Lipoma. NCI Thesaurus. Code C5452.

A rare benign adipose tissue neoplasm of the internal auditory canal, often presenting as an acoustic tumor. It may be intermixed with the vestibulocochlear nerve and may adhere to adjacent structures. 